\title{
How to Manage and Monitor Tangible Fixed Assets Effectively
}

\author{
Vladimir Bukvič \\ GEA College
}

In this paper, the author investigates some conventional tools and criteria-indicators belonging to business analysis, by means of which firms should monitor and assess the effective use of their fixed assets. As fixed assets are an element of the business process, and among the most relevant and biggest resources in terms of value, the author asks how to handle fixed assets in the most economical way possible and how to manage them well. Within this context fall their rational use and optimal exploitation. These questions can be answered by means of indicators such as operating leverage (OL), the rate of return of total assets (ROA), depreciation as an average fixed cost (AFC), and overall equipment effectiveness (OEE). The answers are additionally clarified and supported by calculations of these criteria-indicators on the examples of several concrete cases from the real economic sector. Finally, the author suggests raising awareness among managers and educating them so they may increase control over their exploitation in order to manage them properly and use them effectively.

Keywords: operating leverage, average fixed cost, return on assets (ROA), overall equipment effectiveness (OEE), fixed assets management

\section{INTRODUCTION}

In this paper, we treat one of the key elements of the business process, i.e., fixed assets. We thereby deal with that element of the business process which belongs among the relevant resources of firms. According to resource-based theory, resources form the basis of individual strategies aimed at creating values and implementing activities addressing specific markets and customers in a special way, and thus lead to competitive advantages in terms of forming key competencies (Collis \&amp; Montgomery, 1995, 1998; Porter, 1996; Prahalad \&amp; Hamer, 1990) and achieving lean production (Womack, Jones \&amp; Roos, 1991). Among the firms' resources, fixed assets have the highest value; that is, if we ignore human capital, which does not actually have any price.

However, in spite of the rather high capital expenses (capex) dedicated to acquiring fixed assets in order to increase their production capacities, and thus to be able to follow the increasing demand of customers and technological progress, as well as to be in a position to keep pace with the competition, there are quite a few firms that do not perform well. They do not exploit their assets well enough and rationally. Their investment in fixed assets does not reach a satisfactory return on equity (ROE), nor even an adequate cash flow as planned. Their investment projects were economically justified by investment programs, and better performance expressed by higher net sales revenue, earning before interests and taxes plus depreciation and amortization (EBITDA), net profit, higher ROE, higher return on assets (ROA), higher positive cash flow, etc., were foreseen. If we assume that at the time of making the investment decision the investment projects 
were estimated as being profitable and economically justified, they should have been economically sound, well set up and promising for the firms as investors. Consequently, the following questions might be raised: Why have these projects not been as effective as planned, as they should have been? Further, why did their real performance and effectiveness fall below the planned goals? And last but not least, why don't these investments reach their planned scope, and why do they not fulfill the goals set at the time of decision making?

These are the questions to which we provide no answers in this paper. The answers to these questions are provided in the study "Impact of the Slovenian companies' investment ability on their business performance" (Bukvič, 2020) and in other recent papers (Bukvič et al., 2020a; Bukvič et al., 2020b). Instead, we try only to present some conventional tools and criterial indicators, by which the effectiveness of the exploitation of company assets can be monitored and estimated. At the same time, we want to establish the reasons for not reaching the planned goals. If firms did this consistently, then such annoying questions would not need to be raised. The indicators which will be presented in detail in this paper, and their analytical and indicative values illustrated on a set of concrete practical cases, pertain to business analysis as an empirically oriented science. Without criteria business analysis cannot exist, neither can any analysis of fixed assets, or as Bergant (2013) puts it, an appropriately defined criterion is essential for making information. For this reason, it is crucial to study thoroughly the characteristics of several decision options and find out their consequences.

In theory, in the field of business analysis these criteria or indicators have been well known for a long period of time, and in well-performing firms they are used to their advantage as they help them determine how to effectively manage the assets. In this context, a financial ratio ROA will be presented in detail. By using ROA, firms measure the effectiveness of the exploitation of all the assets available to them. They want to find out what return on these assets is achieved at the level of the whole firm. Further, in this context several non-financial indicators for measuring the effectiveness of the exploitation of individual machines and equipment will be presented as well. Those firms that, some years ago, envisioned in their development strategies the long-term goal of introducing Industry 4.0 and the digitalization of their production and other processes, such as the manufacturing execution system (MES), strongly supported by information and communication technology (ICT), are already intensely implementing them. Thus, they are increasing the effectiveness of the exploitation of their assets, and consequently also their business performance, and they will keep doing so in the future.

\section{OPERATING LEVERAGE AS A SIGNPOST FOR TECHNICAL EQUIPMENT OF THE FIRMS}

In order to improve the productivity of production processes, to improve the quality of the products, to decrease waste, to remove mistakes caused by human beings, to better exploit machines and equipment, to optimize and rationalize the entire production process, and last but not least to take care of humanity, i.e., to protect workers from hard conditions (pollution, noise, heave of heavy loads, monotone manual operations, etc.), firms constantly automate and robotize their production processes. Thus, the labor force is getting substituted by fixed assets and the technical equipment involved in the processes is increasing. In economics it is said that variable capital decreases on behalf of fixed capital increase, which means that in the structure of cost price, the labor cost (wages) decreases and the depreciation cost increases. This phenomenon is called the operating leverage increase. The operating leverage rate (OPR) measures the impact of the sales revenue change on the operating profit or EBIT (Bergant, 2010). If a high percentage of total costs are fixed, then the firm is said to have a high degree of operating leverage (Brigham \&amp; Houston, 2004). Operating leverage also answers the question of how much EBIT increases if the sales revenue increases by one percent. We calculate it by using the following formula:

$\mathrm{OL}=1+\mathrm{FC} / \mathrm{OP}$

$\mathrm{OL}$ - operating leverage

$\mathrm{FC}$ - fixed cost 


\section{$\mathrm{OP}$ - operating profit or EBIT}

According to Bergant (2010), the operating leverage rate can be computed from the change of EBIT and sales revenue:

OLR $=$ Percentage of profit change $/$ Percentage of sales revenue change $=$

$=\left(\mathrm{EBIT}_{1}-\mathrm{EBIT}_{0}\right) / \mathrm{EBIT}_{0} /\left(\mathrm{SR}_{1}-\mathrm{SR}_{0}\right) / \mathrm{SR}_{0}$,

where indexes 0 and 1 denote the beginning and the final sales revenue (SR), and the beginning and final EBIT, respectively.

A necessary condition for computing operating leverage and for using it as a good tool in making investment decisions, and as a good signpost in the sense of increasing the amount of technical equipment in firms or improving it, is to know variable and fixed costs very well. In microeconomics, the distinction between these two kinds of costs derives from cost dependence on production volume. The fixed cost remains independent with respect to production volume until the production capacities change (Tajnikar, Brščič, Bukvič \&amp; Ogrin, 2000). The delimitation between variable and fixed costs in firms is no easy task, for there are some costs that are by nature (and also by economic theory) variable costs, but are designated as fixed costs in real practice. Such a characteristic can be found in labor costs, which have a fixed basis, but their variable part depends on the performance of an individual worker achieving the working standards and norms, and the organizational (production) unit. If we succeed to reach at least $90 \%$ accuracy in the delimitation of costs into variable and fixed cost, it can be said that we have got near the break-even-point, which is crucial for business analysis, and in our case for monitoring the operating leverage as well.

What, strictly speaking, influences the value of operating leverage? The higher the percentage of fixed costs in comparison to variable costs, the higher the operating leverage (Mramor, 1993). By a higher operating leverage, the profit increases rapidly above the break-even-point when all the fixed costs are covered, and conversely, below the break-even-point the loss increases, which can be seen in Figure 1. Below the break-even-point the loss increases, and above the break-even-point it is the profit that increases. We are interested in how fast all this occurs.

The higher the operating leverage, the stronger profit reacts to the change of sales revenue. The ratio between fixed and variable costs is to a great extent defined by technology. By increasing the sales revenue, the rate of the operating leverage decreases. It is not defined in the break-even-point. Then it decreases and asymptotically draws near the value 1 . A high operating leverage means a higher variability of the operating profit or EBIT, and consequently a higher business risk. Business risk can be reduced by a higher sales volume and/or by a higher operating profit (Mramor, 1993).

The firms with a high level of technical equipment, i.e., with a high capital coefficient, also have a high operating leverage. This is typical of the processing industry, such as the chemical, steel, metallurgical, pharmaceutical industries and others. The operating leverage, which is not as high as in the above mentioned industries, has increased in recent years also in all those firms where automation and robotization of processes take place, and thus the percentage of fixed costs increases in the cost price. These processes occur especially in cases where the firms are obliged to adjust to the augmented demand of their customers if they want to either maintain or increase the market shares of their products and oppose their competitors, i.e., to prevent their customers to switch to the competition. A modernization of the production processes takes place by means of fixed capital, i.e., by tangible fixed assets. An increase of tangible fixed assets can be observed in a fashion similar to leverage in physics (moving a heavy burden by means of leverage). It influences the increase of sales, and thus the increase of the operating profit.

Certainly, the operating leverage can also have a negative effect on a firm's performance. This effect appears when in spite of high investment in new fixed assets, in new machines and equipment, the customers reduce or even stop their orders for various reasons. They might be various kinds of reasons from the macroeconomic perspective, due to a recession or force majeure, such as we are facing this year, i.e., the COVID-19 pandemic. They can also be very specific, related to a certain product a firm produces and 
subject to becoming obsolescent overnight due to innovation or a new technological progress, or a new product which supersedes existing ones, or due to new, less expensive products coming from a low-cost country. In all these cases, investments to increase tangible fixed assets become missed or driven investments for the firms. They turn out to be failures. Above all, they are not used and exploited. The firms are left with high and uncovered fixed costs, such as depreciation or high lease instalments if a fixed asset was purchased on a long-term financial lease. Just as the operating leverage positively influences the sales revenue and operating profit due to the increase of fixed capital as a consequence of higher demand and customers' orders, it has a negative influence in the case of an increase of fixed capital as a consequence of investment in tangible fixed assets. The sales decrease, and operating profit even more, which can turn into an operating loss.

\section{FIGURE 1 \\ REVIEW OF THE BREAK-EVEN-POINT AS A MEANS TO UNDERSTANDING OPERATING LEVERAGE}

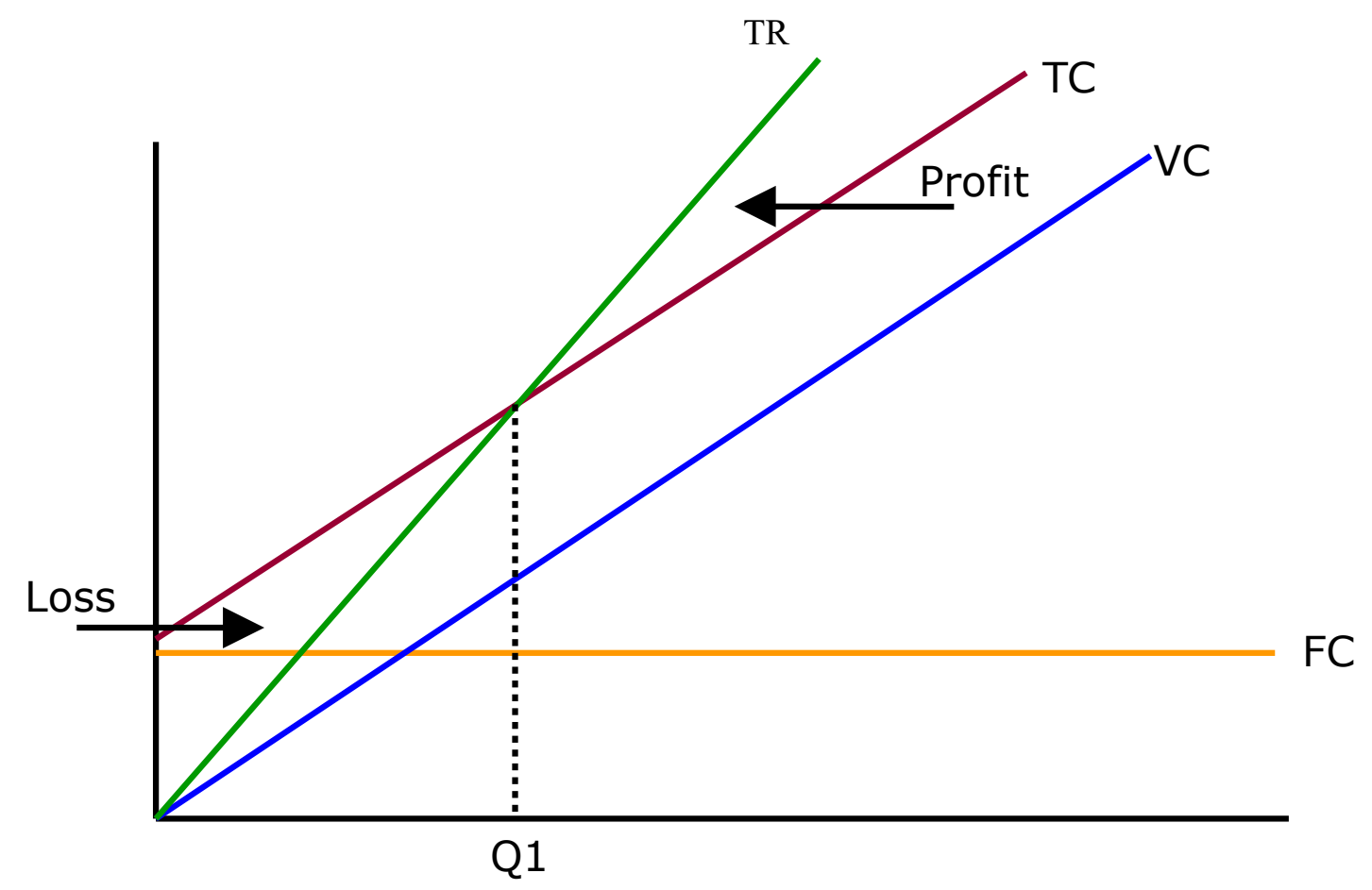

Source: Author's own work

The outcome might be even worse. To increase investment in tangible fixed assets, firms generally do not have enough of their own funds (retained earnings and depreciation), but they do have to increase their debt, they have to either borrow long-term bank loans and credits, or enter financial lease agreements, issue corporate bonds, and similar. It means that by increasing their operating leverage they also increase their financial leverage. The latter answers the question of by how many percent net profit increases if the operating profit increases by one percent. The use of debt, or financial leverage, concentrates the firm's business risk on its stockholders. If the firm earns more on investments financed with borrowed funds than it pays in interest, the return on the owners' capital is magnified, or "leveraged" (Brigham \& Houston, 2004). Financial leverage can be computed by the following formula:

$\mathrm{FL}=\mathrm{OP} /(\mathrm{OP}-\mathrm{i})$

$\mathrm{FL}$ - financial leverage 
OP - operating profit (EBIT)

i - financial cost (interests)

As a matter of fact, financial leverage can also contribute to the improvement of the business performance of a firm, to reaching a higher net profit, but under one condition, i.e., if the sales volume increases. For the management of a firm, it is important to know that a higher rate of financial leverage means, similar to the operating leverage, a higher variability of net profit and therefore greater business risk (Mramor, 1993). If the sales decrease due to the above mentioned reasons, the financial leverage will pull down the firm, under the water. It will immerse the firm and the firm can find itself on the edge of insolvency. Both leverages, i.e., operating leverage and financial leverage, can operate in both directions and they can represent a heavy burden for the firm in the case of black scenarios as far as sales volume is concerned.

There is a saying in theory, which can be confirmed in practice as well, that one should not load high financial leverage on a high operating leverage.

Let us observe a concrete empirical example. The figures are shown in Table 1.

A small firm from the metal processing industry intends to decrease its operating cost by substituting manual work with mechanical work (with machines and equipment). The fixed cost increases due to the purchase of a new machine (additional depreciation of the machine), and variable cost decreases (lower labor cost). Let us assume that the total cost did decrease.

\section{TABLE 1}

\section{SUBSTITUTION OF MANUAL WORK WITH MECHANICAL WORK - OPERATING LEVERAGE}

\begin{tabular}{|l|r|r|r|r|r|}
\hline & Sales & Variable cost & Fixed cost & Total cost & EBIT \\
\hline \multirow{3}{*}{ Firm A } & 200 & 120 & 100 & 220 & -20 \\
& 300 & 180 & 100 & 280 & 20 \\
\cline { 2 - 6 } & 400 & 240 & 100 & 340 & 60 \\
\hline \multirow{3}{*}{ Firm B } & 200 & 100 & 130 & 230 & -30 \\
\cline { 2 - 6 } & 300 & 150 & 130 & 280 & 20 \\
\cline { 2 - 6 } & 400 & 200 & 130 & 330 & 70 \\
\hline
\end{tabular}

Source: Author's own work

By keeping the sales volume the same, the rate of the operating leverage increases, and consequently so does business risk (the variability of operating profit in the last column in Table 1 increases). If the outlook for sales increase is reliable, then the investment decision was justified. By contrast, if this is not so, the firm has increased its business risk. If sales drop, the operating loss will be higher than it would have been without investing in a new machine.

\section{ROA AND EFFECTIVE ASSETS MANAGEMENT}

Return on assets, ROA, is a crucial and widely used financial ratio. It shows how successfully a firm uses its assets. On the one hand, it is used by analysts to measure the return of a firm, and on the other, it serves researchers to predict financial variables and business events.

ROA is computed by taking into account net profit in comparison to the assets for each individual year. As this ratio is relatively important, it is useful to say that profitability of the assets increases if, under the assumption that the speed of asset turnover remains constant, the economy (thriftiness) increases, or if by the given economy the speed of asset turnover increases (Tekavčič \& Megušar, 2002), which can be seen from the following equation: 
$\frac{\text { netprofit }}{\text { assets }}=\left(1-\frac{1}{\text { economy }}\right) x \frac{\text { salesrevenue }}{\text { assets }}$

A recent study by Jewell and Mankin (2011) has shown that, in theory, there are 11 different versions of ROA ratios. The most widely used among them are the following:

$\mathrm{ROA}=$ Net profit $/$ Value of all assets

$\mathrm{ROA}=$ Net profit $/$ Average value of all assets

$\mathrm{ROA}=($ Net profit + Interests $) /$ Average value of all assets

$\mathrm{ROA}=($ Net profit + Interests $(1-$ tax rate $)) /$ Average value of all assets

These four ratios represent more than $75 \%$ of use of all ROA ratios. The use of different versions of this ratio causes certain difficulties in the benchmarking of firms. For this reason, it is opportune not to consider ROA as only one relation, but as a category of relations. This category includes almost every relation that compares net profit from the Income Statement to the value of all assets or to the average value of all assets from the Balance Sheet. However, each version of this relation can have a valid use in a certain context.

In the ROA ratio, regardless of how it is computed, tangible fixed assets are also included among assets in the denominator. If in the benchmark analysis of this ratio, either to the value achieved in the previous year, or to its average value in the industry (or in a subgroup of the particular industry), or to the value of this ratio of high-rated firms in the industry (as this ratio differs strongly according to the type of industry, its comparison is reasonable only with similar firms in the industry), deviations are found downwards, this warns a firm to check how its individual tangible fixed assets are used and exploited, i.e., its machines, equipment production lines, etc. In the firms, this can be done by using tools or indicators such as the rate of capacity use, the rate of capacity employment, the rate of effectiveness, and the efficacy of fixed assets (Pučko, 2006). The most widely used indicator is Overall Economic Effectiveness, OEE, which will be shown and explained in the next section of this paper.

Let us consider, in the context of effective tangible assets management, a concrete empirical case from the automotive industry. We are especially interested in how a low exploitation of a fixed asset influences a firm's business performance and its cash flow. Let us consider the case of a highly productive CNC machine for metal processing. This machine can produce (available capacity) 12000 pieces a day (in three shifts with 8 hours a shift). This metal piece made of aluminum is a constituent part of a turbo compressor, it is an engine bracket, and is basically a semi-product, aluminum cast. This metal piece can be processed through several operations of this CNC machine at the same time, specifically milling, drilling, grinding, turning, etc. The purchasing value of a third CNC machine (it is a double module or a twin) amounts to $€ 1,200,000$. Its economic life span is estimated to 5 years. In time, the CNC machine depreciates linearly and regularly. It operates 250 days in a calendar year (half a month is foreseen for refitting and maintaining) and it produces 3 million pieces. Based on these data, we can compute a depreciation cost for one engine bracket piece as an average fixed cost, AFC. The depreciation cost for a piece amounts to $€ 0.08$. This also represents a cost item in the cost production price approved by the customer (OEM). Under the assumption that the $\mathrm{CNC}$ machine runs normally all the time, i.e., without any deadlock and standstill, and that a given number of engine brackets is delivered to the customer in a one-year period, and, last but not least, that the customer pays regularly, the firm receives an amount of calculated depreciation of $€ 240,000$ within its selling price. This is quite an amount in the cash flow of the firm. While dealing with depreciation, we have to be aware that depreciation cost can be embedded in the value of the work in progress and in the value of finished goods, before they appear as the operation costs and influence the operating profit of a particular accounting period (Mayr, 2020). Each quantity of the brackets produced that is smaller than that produced by the machine with its disposable capacity also means a lower inflow of depreciation or a certain deficit 
in cash flow. At a smaller quantity the produced depreciation as a fixed cost per unit of the product, AFC, is higher. A problem arises when the customer does not accept this higher depreciation per unit of the product as a cost item in the selling price. As the firm does not use a functional method of depreciation, the depreciation cost computed by using the timely linear method is constantly equal. This means that depreciation as cost is accounted totally for the accounting period, and thus it influences the operating profit. Certainly, the operating profit is lower, since with the depreciation cost being equal the sales revenue is lower. Thus, we have a depreciation that can be divided into two categories, the first one being cash depreciation, paid by the customer, and the second one being fruitless (useless) depreciation, which is not paid. This implies that in our case, besides the fact that depreciation as a cost is never a cash expense or outlay, we can affirm that depreciation is not cash receipt or income in total either. This phenomenon can be illustrated graphically as shown in Figure 2.

\section{FIGURE 2 \\ DEPRECIATION COST AT DIFFERENT PRODUCTION VOLUMES}

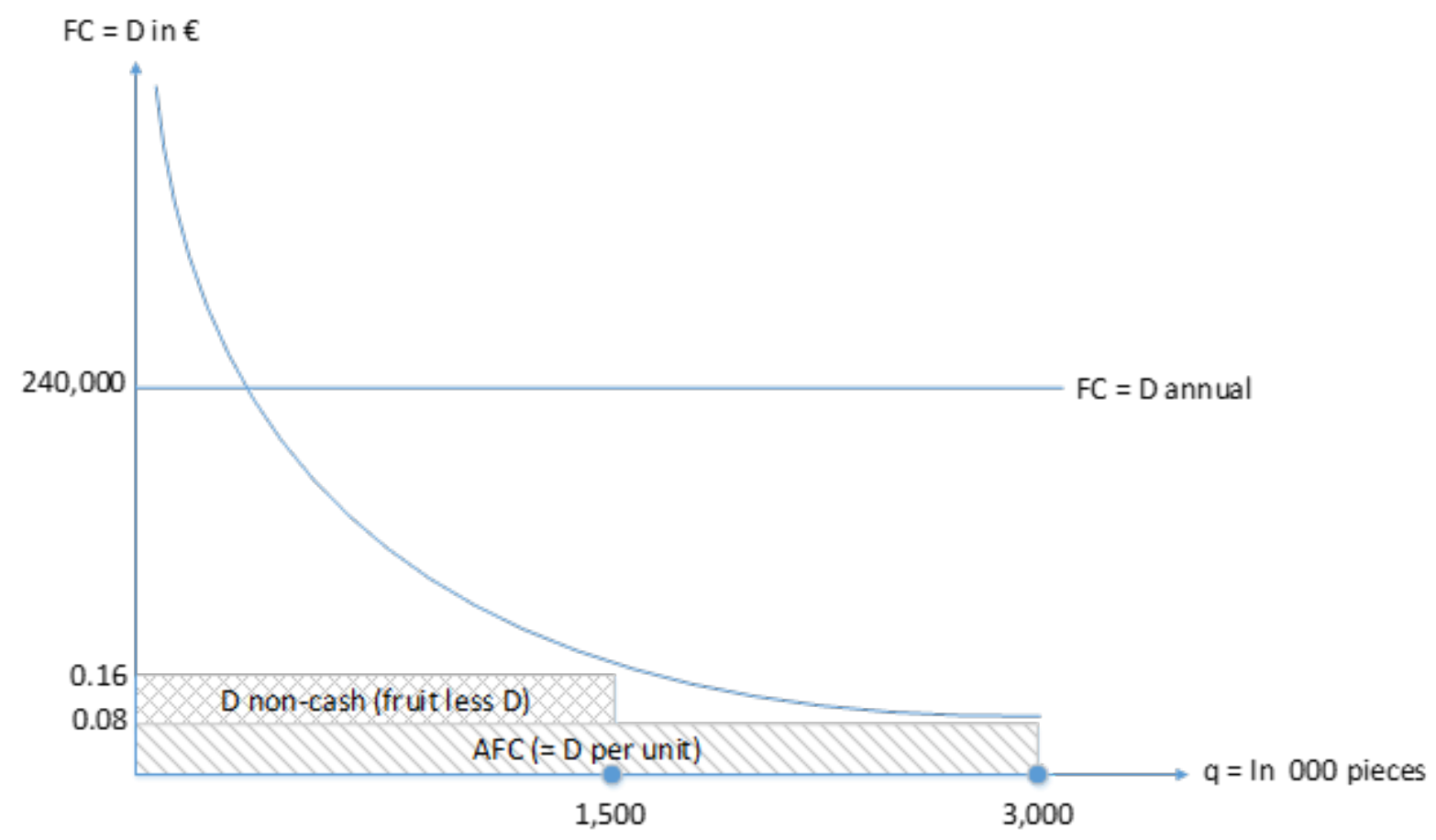

Source: Author's own work

On the basis of this case, we can make the following conclusion: it is very much necessary to keep watch over the full exploitation of the machines and equipment; if not, this reflects on the deterioration of a firm's business performance (lower EBIT due to the lower net sales revenue), it reflects on the financial ratio ROA, which warns us about any insufficient profitability of the assets, and it is also reflected in the cash deficit due to the partially unpaid depreciation.

As we have already referred to the automotive industry, where a strong and long purchasing supply chain dominates, let us expose that the variables of such a chain significantly influence the ROA ratio (Kleindorfer, 2007, as cited in Prašnikar, 2007). While, on one side, traditional supply chain management accounts for only the material cost, production cost, transportation cost, duties and taxes, and conventional warehousing cost, on the other, the firms have started to also account for the production site of their products and services. They have been pushed into doing so by internationalization due to reasons of taxation and other benefits, such as savings deriving from low labor costs. 
The increase of risk caused by the reconciliation of supply and demand leads to more attention being directed towards costs related to stocks and inventories. We argue against the cost having a direct bearing on unsuitable inventories at inappropriate times and in inadequate places. Figure 3 shows the impact of supply chain management on assets. Decisions on what to keep in the firm and what to organize in cooperation, i.e., outsourcing or off-shoring, influence the cost of the proprietorship of the assets and through the supply chain also inventories and other factors of the ROA ratio.

\section{FIGURE 3 \\ IMPACT OF THE SUPPLY CHAIN ON THE ROA RATIO}

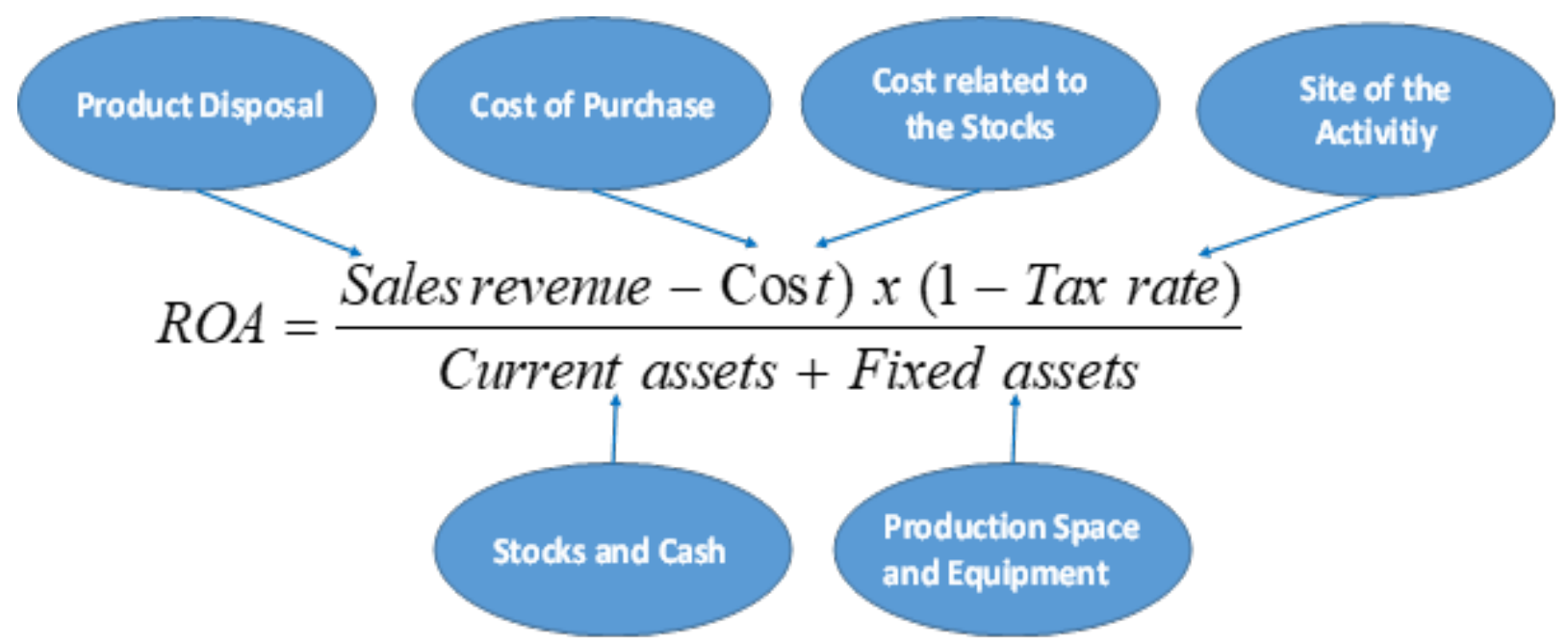

Source: Adjusted from Kleindorfer $(2007,6)$.

According to Kleindorfer (2007) as cited in Prašnikar (2007), a challenge of the modern supply chain is to establish a right balance between the availability of products and services, cost, and assets management. The risks which recently derive from co-operation and exerting pressure on reducing assets, and consequently also on the ROA ratio, are not yet well understood in the firms. In the process of complex globalization, lean and global supply chains are becoming more and more vulnerable to natural disasters and changes in the balance of power. As the above mentioned author says, the management of these kinds of risks will become a key issue to be confronted by the firms.

\section{MONITORING OF OVERALL EQUIPMENT EFFECTIVENESS}

As already written above in Section 3 of this paper, it is very useful to monitor and estimate fixed assets from the perspective of their effectiveness. By effectiveness, what is meant is the disposable capacity of a fixed asset in comparison to the value unit of this asset (Pučko, 2006), which can be defined by the following formula:

Effectiveness of the fixed assets $=$ Disposable capacity / Purchasing value of the fixed assets

If the increased value of the fixed assets in a firm also makes for a higher disposable capacity, it will positively influence business performance. The capacity or efficiency of a fixed asset represents the possible volume of business outcomes, generated by the fixed assets of a firm, certainly by those that are in use. In our case, fixed assets are mainly understood to be tangible fixed assets, such as buildings, equipment, longterm production plants, etc. Intangibles, such as patents, licenses, patterns, models, etc., are not the subject of this paper. 
In theory, there are several kinds of capacity or efficiency of fixed assets. These are theoretical or inbuilt capacity, disposable capacity, planned capacity, and real or actual capacity of the fixed asset. The first one cannot be achieved in real life, for it is an ideal state. The second one represents an actually feasible and achievable volume of outcomes in a certain time unit. Disposable capacity can be defined in the following way: from in-built capacity expressed in working hours, the days-off in a business year are subtracted, and also the time (days) needed for annual maintenance of the fixed assets, time (days) needed for regular (daily) maintenance, and also time (days) related to the objective halt of the work on these fixed assets. When we try to assess what the disposable capacity of a fixed asset could be, we cannot avoid the number of working shifts in the firm. We have to account for the maximal possible number of shifts. The planned capacity of a fixed asset is that volume of business outcomes which is set in a business plan and which can be achieved by means of fixed assets in a certain period of time (Pučko, 2006). It is usually lower than disposable capacity. Real or actual capacity is defined by considering the unpredictable halts of machines and equipment occurring in an accounting period and expressed in days, subtracted from the planned capacity of the fixed asset. The causes for these halts are of various kinds, such as a shortage of electricity, lightning strike (which destroys the software of the machine), late delivery of material, bad quality of the raw material, unforeseen defects, long waiting times for spare parts, etc. As a constituent part of the firms' annual business plan, a balance of the capacity of fixed assets is set up, on which basis the different kinds of capacities of fixed assets described above are defined.

Measuring the capacity or efficiency of an individual fixed asset is usually not particularly problematic; however, it is difficult to measure the capacity of all the assets. It is quite a demanding task, for it can be expressed differently. For example, bottle necks must be taken into account, and following them, the total capacity can be assessed. In theory, we distinguish two types of capacity, i.e., extensive capacity and intensive capacity. Extensive capacity refers to time disposable for work, for operation on a certain piece of the fixed asset, or on a group of equal or similar fixed assets in a certain time period. Intensive capacity is a term for the feasible quantity of business outcomes in a time unit (Pučko, 2006). Integral capacity is the mathematical product of both.

We proceed with two concrete cases from real business praxis showing how in a core production plant, producing cores of silica sand by two procedures (cold box and the Croning procedure) for the needs of foundries, mainly for the automotive industry, an Overall Equipment Effectiveness, OEE, is monitored. As a matter of fact, how do they exercise control over the operation of their core shooter machines?

For a better understanding of our two cases, let us shortly explain some terms used in this particular field, i.e., the production of silica sand core by the core machines.

There are three production processes used for producing cores: cold box, hot box or Croning, and inorganic.

A core is a device used in casting and molding processes to produce internal cavities and re-entrant angles. The core is normally a disposable item that is destroyed to get it out of the piece. Cores are most commonly used in sand casting, but are also used in die casting and injection molding. For example, cores define multiple passages inside cast engine blocks. One model of a GM V-8 engine requires 5 dry-sand cores for every casting.

For producing cores, core shooter machines or sand core making machines are needed, as well as core boxes as special tools installed in these machines. The core boxes are made by tool makers and are numerous, each for a special kind of core.

Let us now take the first example to find out what the OEE is for a concrete core shooter machine. The data are real, taken from a core production plant that wants to remain anonymous.

Let us assume that the core machine EUROMAC (Croning procedure) can theoretically produce 180 cores in one operation shift (8 hours), or 22 cores per hour.

In 24 hours (3 shifts, 8 hrs each) the core machine EUROMAC can theoretically produce 540 cores. 
Three workers (each in one shift) can produce 450 cores on this core machine in one day.

The OEE can be computed as follows:

Real (actual) operation time: 24 hrs

Theoretical operation time for 45 cores: 450 cores / 22 cores an hour $=20.45 \mathrm{hrs}$

Theoretical operation time for core of good quality / Real operation time: $20.45 \mathrm{hrs} / 24$ hrs $=85.2 \%$ OEE.

Let us take the second example to find out the OEE for an actual core shooter machine. Similarly, the data are real and taken from the same core production plant.

Let us assume that the same core machine as in the first example, EUROMAC (Croning procedure), did not operate 2 hours in one day (possible reasons: defect of the core machine, shortage of electricity, replacement of parts, delay of silica sand delivery to the core machine, etc.).

Disposable time of the core machine operation: $24 \mathrm{hrs}-2 \mathrm{hrs}=22 \mathrm{hrs}$

Disposable time / Planned time $=22 \mathrm{hrs} / 24 \mathrm{hrs}=91.7 \%$

In this case, the core machine produced 474 cores in the disposable time of 22 hours. Let us not forget that the core machine can produce 22 cores an hour.

Disposable time: 22 hrs

All cores produced in the disposable time: 474 cores

Theoretical time for the production of 474 cores: $474 / 22=21.54$ hours

Theoretical time / Disposable time: $21.54 \mathrm{hrs} / 22 \mathrm{hrs}=97.9 \%$ performance

We have found out that out of 474 cores only 450 cores were of good quality. 24 cores were rejected as waste.

$21.54 \mathrm{hrs}=94.9 \%$ quality

Disposal $\times$ Performance $\times$ Quality $=91.7 \% \times 97.9 \% \times 94.9 \%=85.1 \%$ OEE.

A loss of $15 \%$ of the working day (3 shifts) is equivalent to 3.6 of the operation hours lost.

This loss must be a warning to the foreman to undertake the steps necessary to prevent any further halting of the core machine.

On top of that, let us stress that in this particular core production plant the production process is completely digitized. Several sensors are installed at the core machines, which communicate all the necessary data about the core machines, the characteristics and data about the production and the products (cores) to the ERP system (enterprise resource planning). Enterprise resource planning is the integrated management of main business processes, often in real time and mediated by software and technology. A firm can use it to collect, store, manage, and integrate data from many business activities. ERP systems track business resources, such as cash, raw materials, production capacity, and also various kinds of orders, such as work orders, purchase orders, payroll, etc.

All the data related to the activities described in a production work order are transmitted by a MES (manufacturing execution system) data collection module. The manufacturing execution system digitizes manufacturing processes and integrates business systems using a cost-effective, high-quality, and resourceefficient methodology based on Industry 4.0 technology. Operational visibility can be improved by near real-time information, which increases reliability and product traceability using solutions based on the 
Internet of Things (IoT). The reported data collected from the lower levels of individual process are recorded in MES. These data are used for the analysis of the entire business process and sent back to ERP.

This has been implemented with the introduction of SinaproMES software solution modules. The process, from receiving the customers' orders to product delivery, has been shortened (a lean production concept). The capacities, effectiveness, and reliability of the machines and equipment have been increased significantly (total management of the productivity). The quality of the products has been improved (fewer complaints and claims coming from the customers). The firm keeps on monitoring worker shifts, raw material (silica sand), and the availability of the machines and equipment (OEE). The firm supplies its customers just-in-time (JIT). MES hinders the occurrence of faults and defects (Poka-Yoka). The whole production process has been improved (PDCA).

\section{CONCLUSION}

In this paper, we have exposed one of the key elements of the business process, or one of the crucial resources if we lean either on business analysis as a science, which is by its characteristics an empirical and generally cognitive method (Tintor, 1992a and 1992b; Mellerowicz, 1961 and 1952; Lipovec, 1983), or on resource-based-theory, which helps us understand how a firm reaches its comparative advantage and how it keeps it through time (Barney, 1991; Teece, Pisano \&amp; Shuen, 1997). We dealt with tangible fixed assets from the perspective of how to handle and use them properly and economically, how to manage them well. This includes their rational use, their optimal exploitation, and making decisions on when it is reasonable and economically justified to replace them (although the last is not a subject of this paper). As such, the paper deals with the element of the business process which has the highest value among the resources of firms. Usually, firms spend a lot of money on purchasing tangible fixed assets, which constitutes more or less risky long-term investment decisions.

Firms usually experience a shortage of their own funds. For this reason, when closing the financial budget of fixed assets, mainly those of high value, borrowed funds have to be acquired as well. Issuing new stock for investment funding is quite rare for corporations. Investment decisions on purchasing new fixed assets are long-term strategic decisions, the consequences of which show up in the long run.

In this paper, investment decisions related to enlarging production (in order to increase production capacity) are not dealt with. What is addressed is the question of how to use and exploit the existing fixed assets, mostly in order to generate maximal returns in their economic life span, which finally influences their business performance. Similar to how we say that it is the worst possible scenario for a firm to have its cash tied up in stocks and inventories - stocks and inventories are a necessary evil - we can assert the same for fixed assets if they are not used and exploited. It is true that stocks and inventories represent real assets, they are the firm's property, but unfortunately this property does not bring anything to the firm or to its owners, no returns, no cash. Conversely, if a firm cannot sell its stocks of finished goods, they gradually lose their value, and finally the firm is forced to sell off the stocks and hence its property. Something very similar can be claimed for fixed assets. A firm has to spend a lot of funds to purchase them. It even has to borrow the capital to invest in the fixed assets. If these rather expensive fixed assets do not generate cash, they are a wasted investment. Management should already be worried if these assets do not operate at full capacity, if the sales revenue drops and the operating cash flow decreases, therefore, if these assets do not generate added value for the owners.

Fixed assets are not supposed to be sold like stocks of finished goods. As far as disinvestment is concerned, firms should have recourse to extreme measures, especially when the management finds out that a firm does not need certain fixed assets anymore. However, they would only lose if they sold them. They would get less than they paid for them. Consequently, the fixed assets must be fully exploited and properly and regularly maintained. Preventive maintenance is crucial, since it allows the firm to preserve the operational condition and capacity of its machines and equipment. In this paper, some tools and criterial indicators, such as operating leverage, ROA, OEE, and AFC, are presented and applied to practical cases. They may help the management of a firm to keep watch over the rational use of their fixed assets and monitor their functionality and effectiveness. 
We suggest raising awareness among managers and educating them so they may view fixed assets as representing some of the key resources of any firm. From the perspective of the basic postulates of resourcebased-theory, which states that resources are long-lasting, constant, difficult to define and not easily understood, as well as being very difficult to transfer and irreproducible since they are owned by firms, management should take over their control, so that they can be managed properly.

\section{REFERENCES}

Barney, J.B. (1991). Firm Resources and Sustained Competitive Advantage. Journal of Management, $17(1), 99-120$.

Bergant, Ž. (2010). Fundamentals of Business Performance Analysis (second, amended edition). Ljubljana: Institute of Management Accounting at the College of Accounting and Finance.

Bergant, Ž. (2013). Business Performance Analysis from Theory to Practice (Accounting and Financials Aspects). Ljubljana: Institute of Management Accounting.

Bole, V., Bukvič, V., Prašnikar, J., \& Tekavčič, M. (2020). Impact of Companies’ Investment Ability on Business Performance. European Journal of International Management, in publishing.

Brigham, E.F., \& Houston, J.F. (2004). Fundamentals of Financial Management (Tenth edition). Mason: Thomspon. South-Wester.

Bukvič, V. (2016). Industry 4.0 and Its Implementation in Our Industry. Professional meeting of MIT users on 11 October 2016 in Kranj.

Bukvič, V. (2020). Impact of the Investment Ability of Slovenian Companies on Their Performance. Research in Publishing Ljubljana: Faculty of Economics.

Bukvič, V., Prašnikar, J., \& Tekavčič, M. (2020). Impact of Corporate Investment on Business Performance: The Case of Slovenian Firms for the Period 2000-2017. Journal of Economic and Business Review, in publishing.

Collis, D. J., \& Montgomery, C. A. (1995). Competing on resources: Strategy in the 1990s. Harvard Business Review, 73(4), 118-128.

Collis, D. J., \& Montgomery, C. A. (1998). Creating corporate advantage. Harvard Business Review, 76(3), 70-83.

Jewel, J.J., \& Mankin, J.A. (2011). What is your ROA? An investigation of the Many Formulas for Calculating Return on Assets. Academy of Educational Leadership Journal, 15(Special Issue), 79-91.

Kleindorfer, P.R. (2007). Implications of globalization and sustainability for emerging business models. In J. Prašnikar and A. Cirman (ed.), New Emerging Economies and Their Culture (pp. 1-15). Nova Science Publishers, Inc.

Lipovec, F. (1983). Business Performance Analysis and Planning. Ljubljana: ČGP Delo - TODZ Gospodarski vestnik.

Mayr, B. (2020). Accounting from A to Z. Definition and Categorization. Accounting PlatformAmortization - Some Additional particularities. Ljubljana: Institute of Management Accounting.

Mellerowitz, K. (1952). The Worth of a Company as a Whole. Essen: Girardet.

Mellerowitz, K. (1961). General Business Management. Berlin: Springer-Verlag.

Mramor, D. (1993). Introduction to Corporate Finance. The Manager Series. Ljubljana: Gospodarski vestnik.

Porter, M.E. (1996). What is strategy? Harvard Business Review, 74(6), 61-78.

Prahalad, C.K., \& Hamel, G. (1990). The core competence of the corporation. Harvard Business Review, 68(3), 79-91.

Pučko, D. (2006). Business Performance Analysis. Textbook. Ljubljana: Faculty of Economics.

Tajnikar, M., Brščič, B., Bukvič, V., \& Ogrin, N. (2000). Management Economics with Practical Cases. Textbook. Ljubljana: Faculty of Economics.

Teece, D.J., Pisano, G., \& Shuen, A. (1997). Dynamic capabilities and strategic management. Strategic Management Journal, 18(7), 509-533.

198 Journal of Accounting and Finance Vol. 21(5) 2021 
Tintor, J. (1992a). The Concept, Genesis and Subject of the Economic Analysis of Business Performance (1). Ekonomski analitičar, November. Zagreb: TEB-biro za privredno planiranje.

Tintor, J. (1992b). The Concept, Genesis and Subject of the Economic Analysis of Business Performance (2). Ekonomski analitičar, December. Zagreb: TEB-Biro za privredno planiranje.

Womack, J.P., Jones, D.T., \& Roos, D. (1991). The Machine that Changed the World: The Story of Lean Production. New York: HarperCollins. 